Miriam Hartlapp*

\title{
Revisiting patterns in EU regulatory social policy: (still) supporting the market or social goals in their own right?
}

https://doi.org/10.1515/zsr-2019-0003

\begin{abstract}
Despite the fact that economic concerns are the main driver of the EU integration process, integration does carry a substantial social dimension. Yet, it remains an open question whether this social dimension 'only' supports the market or whether goals such as social justice, solidarity and employment conditions are independent of or even work against goals of market efficiency. To address this question the paper presents an original dataset on all 346 binding EU social policy acts adopted since the Union's founding. In a descriptive approach, I contrast instruments and dynamics in areas and subfields connected more closely to the common market with those more directly constituting a social dimension in its own right. On this basis, I argue that the shape of EU social policy has substantially changed, strengthening its market-supporting dimension while weakening policy focused on its social dimension. The paper opens up for discussion possible political dynamics driving these patterns.
\end{abstract}

Keywords: EU social policy, regulation, labour law, freedom of movement, party politics

\section{Introduction ${ }^{1}$}

With the European Union (EU) in crisis, the social dimension of Europe is often referred to as a solution to some of the Union's most pressing problems. The Pillar of Social Rights proposed in 2017 by the Commission to render the Eurozone more resilient, or Juncker advocating a Youth Guarantee to address hardship resulting from the financial and economic crisis are two prominent exam-

1 I presented earlier versions of this paper at the 2015 Network Meeting EU Economic and Social Integration in Leipzig and at the 2016 ECPR Regulatory Governance Conference Tilburg. I wish to thank the participants, the anonymous reviewers and Wolfgang Günther for helpful comments as well as Monika Rohmer and Charly Uster for research assistance.

*Contact: Prof. Dr. Miriam Hartlapp, Otto-Suhr-Institut für Politikwissenschaft, Freie Universität Berlin, Ihnestrasse 22, 14195 Berlin, email: miriam.hartlapp@fu-berlin.de 
ples. At the same time EU social policy is often contested for doing too much (red tape as Brexit advocates argued), for not doing the right thing (conservative voices, e.g. when considering liberal anti-discrimination policies), for only supporting market integration or for simply not doing enough to tackle existing problems (Lynggaard 2016). The potential of social Europe to respond to and fund these hopes and criticisms is inherently tied to the question whether EU regulatory social policy (still) supports the market or provides for social goals in their own right.

In the early and mid-1990s researchers asked whether EU social policy is best characterized as market-supporting, i.e. seeking market efficiency, or whether a substantial EU social dimension existed in its own right (Leibfried/Pierson 1995; Ross 1994; Streeck 1995). From this latter perspective social justice, solidarity and favorable employment conditions are goals a market cannot achieve, however efficient. Social policy in its own right can be justified for reaching these goals (Prosser 2006). This divide continues to play an important (implicit or explicit) role in research on EU integration and social policy. It informs recent assessments of the relationship between economic and social goals in the European Semester (Copeland/Daly 2018; Crespy/Vanheuverzwijn 2017; Maricut/Puetter 2018), studies of EU employment policy (Mailand/Arnholtz 2015) or the social investment approach (De la Porte/ Natali 2018). I share with these works an interest in the underlying nature of EU social policy. However, going beyond existing studies on specific policies I provide here a systematic analysis of EU regulatory social policy.

Why study regulatory policy? The notion of Social Europe or EU social policy is widely used, but no clear-cut definition exists. Frequently national social policy is an (implicit) reference point. Yet, national and EU social policy differ in their instrument mix and the issues each address. Typically, at the national level social policy is associated with the welfare state, which distributes money to those at risks of unemployment, old age, health or sickness. The EU budget is limited to only a fraction of national budgets and far-reaching direct financial transfers are not an option (Schmid 2018: 177). This renders distribution comparatively less relevant at EU level. Throughout the integration process nation states have been reluctant to transfer powers on welfare state issues to the EU and only in the early 2000s did member states agree to coordinate policies on issues such as employment (Heidenreich/Zeitlin 2009), pensions (Guidi/Guardiancich 2018) and poverty (Copeland/Daly 2012) - hoping to learn from each other's successes and failures via the Open Method of Coordination (OMCs). However, coordination does not seem well suited to assess the nature of EU social policy. Research demonstrates increasing skepticism on the OMCs 
capacity to steer policy (Copeland/Haar 2013; Kahn-Nisser 2015; Kröger 2009). Moreover, the OMCs have been criticized for their focus on market support (Copeland/Daly 2018; Crespy/Vanheuverzwijn 2017; De La Porte/Heins 2015). In this light it seems reasonable to focus our analysis on regulation as an empirically relevant part of EU social policy - not least because the EU has been described as "regulatory state" (Majone 1993) - and a more likely case to find social policy in its own right. Put differently, if we do not find that regulatory policy advances social goals in its own right, we have good grounds to question the capacity of EU social policy more broadly to respond to and fund the hopes and criticism outlined above.

While for scholars of EU social policy the focus on regulatory instruments is not new, systematic quantitative assessments cover the period up to the crisis only (Falkner et al. 2004; Haar 2009) or analyses only provide case study evidence (Mailand/Arnholtz 2015). I present an original dataset of all 346 pieces of binding regulatory social policy (1958-2017) and an objective aggregate measure to characterize EU social policy output as either market-supporting or social policy in its own right. On this basis I argue that the shape of EU social policy has substantially changed, strengthening its market-supporting dimension, while social policy in its own right has been weakened. Exploring possible causes for the distinct dynamics supporting the market or seeking social goals in their own right, I point at the relevance of interest based factors and political contestation to be included more systematically in aggregate analysis of EU social policy dynamics.

This paper proceeds as follows. The next section (2) outlines the theoretical argument that instruments related to market-supporting social policy differ from instruments seeking social justice, solidarity and employment conditions in their own right. I then introduce the dataset covering all social policy acts adopted from the founding of the EU until the end of 2017 (3). Section 4 provides a big picture analysis of EU regulatory policy over time. Next, section 5 zooms in to developments in three subfields particularly relevant to the argument that there are two types of social Europe that exist, which differ in their instruments, as well as timing, stability and innovation capacity. Finally, potential drivers of the patterns and dynamics are discussed (6) before section 7 concludes. 


\section{What for? Regulating to enhance market efficiency or seeking other (social) goals}

To guide our thinking about social policy developments in the EU this section argues that regulation can be enacted to either enhance market efficiency or to seek (social) goals that cannot be reached by markets. To clarify the difference between the two types of social policy I briefly retrace a more general line of reasoning in regulation theory (cf. Hartlapp/ Rauh 2013), before I return to the EU policy debate.

I start by discussing the goals of regulation. Markets are typically regarded as means to produce the optimal allocation of resources in an equilibrium of economic supply and demand. Governments provide rules to enhance the allocation function of markets and intervene where markets fail, e.g. where preferences are time-inconsistent or information asymmetries exist. This is particularly important for goods or services that are in the public interest. We frequently find examples for such intervention in the area of social policy, e.g. policies that provide incentives to invest into skills in order to improve the employment perspective of market participants. From this perspective regulation is "always second-best" (Prosser 2006: 366), because it is justified (only) to support market mechanisms in the allocation of resources. We can distinguish this view from a second perspective on public regulation. Here, the goal of government intervention is not to reach perfect competition in the market. Rather intervention seeks to alter the very quality of markets. Regulation is addressing misallocation from a moral point of view and is thus seen as "balancing ... competing values setting out the sort of society we wish to live in" (Prosser 2006: 375). Such reasoning exposes a radical divide between two goals of regulation. In the first view, the goal of public regulation is to support or increase efficiency of market allocation. In the second view, the goals are to support or increase social justice or solidarity.

We can broaden this argument to include reasoning about the actors involved. For Majone (1993) non-majoritarian institutions and technocratic actors are best at regulating markets efficiently. Policies for social goals in turn require political justification since they will render some better off than others. Put differently, while market efficiency is best regulated through technocrats resetting the conditions for successful market allocation processes, social goals need 
to be justified and decided upon by politicians. ${ }^{2}$ Equipped with this general perspective on regulation we now turn to the EU.

In the late 1980s and 1990s, when greater numbers of social policy acts were adopted, a virulent debate on the rational or nature of these acts emerged. Streeck (1995) argued that a two tier social policy existed: social policy in its own right - or as he framed it, instruments assuring "industrial and social rights" (Streeck 1995: 40) - at the national level and social policy at the EU level,

suited to market-making by way of negative integration and efficiency enhancing regulation. This is because the removal of barriers to cross-border trade and mobility is less threatening to national sovereignty and less demanding on democratic legitimation than the creation and enforcement of rights and obligations of citizenship (Streeck 1995: 34).

Consequently, social policy at the EU level would be produced in a collateral manner at best, and would affect primarily areas with a functional link to the free movement of workers in the EU common market (Leibfried/Pierson 1995). This reflects an understanding of regulation enacted to support the allocation function of markets. Social policy that would balance competing demands would in turn remain at the national level. Contrasting with Majone (1993) who favours a technocratic origin of measures, Streeck (1995) stresses the lack of political demand from member states. Others have pinpointed the difference between EU policies supporting or enforcing the market on the one hand and market correcting or market cushioning policies of a more interventionist nature on the other hand (cf. Sbragia/ Stolfi 2008: 133). For these scholars, marketcorrecting instruments sought other goals than efficiency. More specifically, the emerging corporatist policy community was analysed as a driver of a genuine EU social policy (Falkner 1998). This, again, points at political dynamics to explain social regulation.

More recently, the question whether EU social policy is supporting the market or exists in its own right was revived. The distinct camps draw on fundamentally different arguments. On the one side, authors employ Polanyi's countermovement to argue that the creation of the market will be answered with an embedding of the market through social policy. Concisely, "[m]arket-making produced market-modification by embedding it in an underlying social logic" (Caporaso/Tarrow 2009: 597; similarly Eigmüller 2013). Empirically the authors

2 Majone (1993) contrasted regulation (for efficient markets) with distribution (for social goals) as different types of instruments. The analytical distinction along the line of goals and actors, however, can also be applied to different types of regulation. 
draw on developments in EU anti-discrimination policy. In a critique Höpner and Schäfer (2012, cf. already Streeck 1995: 44) argue that anti-discrimination policy is not sufficient evidence. First, the authors claim that the policy area is logically conducive to arguments on both sides. Anti-discrimination policy at the same time enables optimal allocation processes on the market and accords individual social rights that cannot be reached by markets alone. Secondly, they argue that EU market integration is undermining national social policy (Streeck's domestic tier) more rapidly than political battles for EU social policy in its own right can be won in Brussels (Höpner/ Schäfer 2012). Setting the argument on thorough theoretical grounds has much merit. Yet, empirical support for either side remains sparse. In studying all adopted social policy regulation since the founding of the EU, I both provide a more systematic empirical approach to this problem and add to existing studies.

\section{Empirical approach}

As outlined in the introduction this paper focuses on regulatory social policy. The universe of analytically relevant cases are all binding EU social policy acts (regulations and directives). I retrieved data from EurLex for the period 1958 when the first act was adopted at the EU level to the end of 2017. EurLex covers all formal acts adopted by the EU institutions. To capture as many social regulation acts as possible, disregarding e.g. portfolio lead, I use two distinct search logics. I combine a directory code search ${ }^{3}$ with a keyword search for 'Social Policy' and 'Worker Mobility'. The resulting data is merged, cleaned up and double entries deleted. Acts exclusively based on the Euratom treaty are excluded as well as acts that are geographical extensions or those that specifically apply to single Member States without substantial policy advances. This results in a total of 346 regulatory EU social policy acts. In the following analysis revisions, codifications and amendments referring to a predecessor act in the title are included but displayed separately as modifications $(\mathrm{N}=200)$. This allows for

3 The codes covered are freedom of movement for workers (05.10), general social provisions (05.20.05), European Social Fund (ESF, 05.20.10), working conditions (05.20.20), employment and unemployment (05.20.30), social security (05.20.40), approximation of certain social provisions (05.20.50), insurance related to the right of establishment and freedom to provide services (06.20.20.10), social conditions of transport policy (07.20.40.20), health protection (15.30), and European citizenship (20.20). 
differentiation between acts that improve existing standards and acts that define new standards, indicating policy innovation.

To objectively measure market-supporting social regulation versus social policy in its own right, we need an indicator applicable at an aggregate level and consistent over time. The Treaty base fulfils these criteria. Every directive, decision and regulation refers to a specific article in the applicable EU treaty. The EU founding treaty considered the coordination of the member states' social-security systems to be a precondition for the free circulation of people and introduced the principle of equal pay for male and female workers. In the following decades, more and more competences were transferred to the EU, in particular the Single European Act (1986) and the Maastricht Treaty broadened the areas of EU social policy. In addition, decision-making in the interinstitutional process was eased by allowing for qualified majority voting in many sub-fields of social policy (Falkner 1998: 56-77). Over time the numbering of the articles has changed, not least to accommodate for competence expansion, but the treaty base can be easily traced back throughout the history of EU integration. This fulfils the criterion of time consistency.

A second aspect is equally important for my argument. Assessing the substance of the treaty articles allows linking them to either the market making or the social policy in its own right argument. This allows classifying large numbers of acts according to their dominant logic without subjectively assessing their content. Two caveats remain. First, the treaty base captures the dominant logic of an act from a bird's eyes perspective. While arguably a good measure across a large number of acts, it might be misleading in a single instance. The agenda setter might choose the treaty base for strategic reasons, e.g. to allow for decision-making under qualified majority rather than unanimity. Yet, this is the exception rather than the rule. Second, and this is a trickier point, we may assume that the two types of goals are not mutually exclusive. Conceptually a market-supporting rational may entail some notion of broader societal wellbeing in its own right, too. In fact both perspectives may simply coincide in the same policy that aims to "create free but fair markets" (Höpner/Schäfer 2012; also Windholz/Hodge 2013). Yet, non-exclusivity should not a priori introduce bias as long as acts qualifying as non-exclusive do not cluster in only one of the two types. We spot checked our data and find (rare) examples for acts coded as "genuine social goals" on the basis of their treaty article that also further the market (e.g. anti-discrimination) as well as acts based on market-supporting treaty articles that also benefit genuine social goals (e.g. residence rights). Future studies should follow up on this point to assess how frequently both goals coincide in EU social policy to better understand whether this might be a consti- 
tuting characteristic of EU social policy. For the purpose of this article, however, the treaty bases seems to be a meaningful and at the same time sufficiently objective measure to operationalize the concepts of interest.

How to tell the two logics apart when you see them? Part of the treaty articles connect directly to the market freedoms. This is the case for articles under title IV, which support the four freedoms of movement. Chapter 1, in particular, focuses on workers and comprises provisions that ensure non-discrimination on ground of nationality and administrative practices (Art. 45 and 46), social protections necessary for worker mobility (Art. 48) as well as provisions assuring mobility for self-employed (Art. 53). Under a different title Art. 21 enshrines free movement as a fundamental right of every EU citizen. I classify acts that draw on these and related treaty articles as market-supporting (MARKET). Title X, in turn, is dedicated to social policy. Here, reaching social goals rather than market efficiency is the objective. In particular, articles protect workers against health or social risks and assure good working conditions (Art. 153), empower the weaker part in the relationship of management and labor (Art. 154 and 155) or transfer rights for equal pay between women and men (Art. 157) and promote cooperation to assure individual protection in social matters (Art. 160). Under different titles Art. 19 enshrines non-discrimination as a fundamental right of EU citizens and Art. 21-24 grant citizens political rights and protection, while Art. 168 seeks public health. Equally, articles that envisage the regulation of distributive instruments such as the European Social Fund (Art. 164) and the European Structural Funds (Art. 175) seek intervention in market allocation to integrate disadvantaged people into society and ensure fairer life opportunities for all - thus reaching goals other than market efficiency. Subfields drawing on these and related treaty articles are classified as social policy in its own right (OWNRIGHT).

Subject areas (Free Movement of Workers, Social Provisions, Funding, Management \& Organization, Others) are exclusive at the level of treaty articles. At a hierarchically lower level, subfields draw on different treaty paragraphs or subparagraphs. In exceptional cases, different subfields might draw on the same treaty base (e.g. Art. 21 or Art. 153). In these cases, I assessed subfields individually by checking the substance of the act. ${ }^{4}$ Some subfields could not be classified into either of the logics, e.g. transport (Art. 91 and 94) or the establishment

4 Where the treaty article is of very general nature or concerns formal procedures rather than substantial characteristics (e.g. Art. 100 on institutional provisions or Art. 235 on decision procedure) I classified the subject area by individually checking the substance of the act, too. 
of committees (Art. 134) or the collection of information and statistics (Art. 337 and 338). These subfields are marked as not assigned (n.a.).

The following analysis uses the data in a descriptive manner. Social policy patterns are contrasted with general policy developments in the EU as described in the cross-sectoral study by Häge (2011; similarly Kassim et al. 2017).

\section{The big picture: EU social policy 1958-2017}

At the inception of the EU, social policy developments were slow to take off. Yet, the EU adopted an impressive number of acts since. The social acquis consists of 346 acts at the end of 2017 (including modifications). In figure 1 self-executing regulations show the highest aggregate numbers (total: 238). Typically, these regulations lay down general policy principles. Thus, despite being directly applicable, their substantial impact is often limited. Directives (total: 108), in turn, are generally considered the most important form of legislative policymaking at EU level. They fix common minimum standards that are binding to member states but leave some room for how to reach these goals.

Turning to instrument types, we see that the number of regulations rose slowly but steadily with a sharp rise occurring after 2002. A change in decisionmaking accounts for this. Since the adoption of the Nice Treaty, joint EP and Council regulations have almost entirely replaced Council acts. Directives show distinct dynamics. The Commission proposed virtually no social policy directives in the early decades. The Council adopted the first directive in 1975 only. From then onward numbers grew constantly with more pronounced developments taking place since the mid-1980s and particularly in the 1990s. The last decade is marked by a flattening curve and substantially fewer EU social policy directives. This contrasts with a further widening and deepening of social policy competences and points to the relevance of institutional and interest based explanations, which we will explore in more detail in section 6 . 


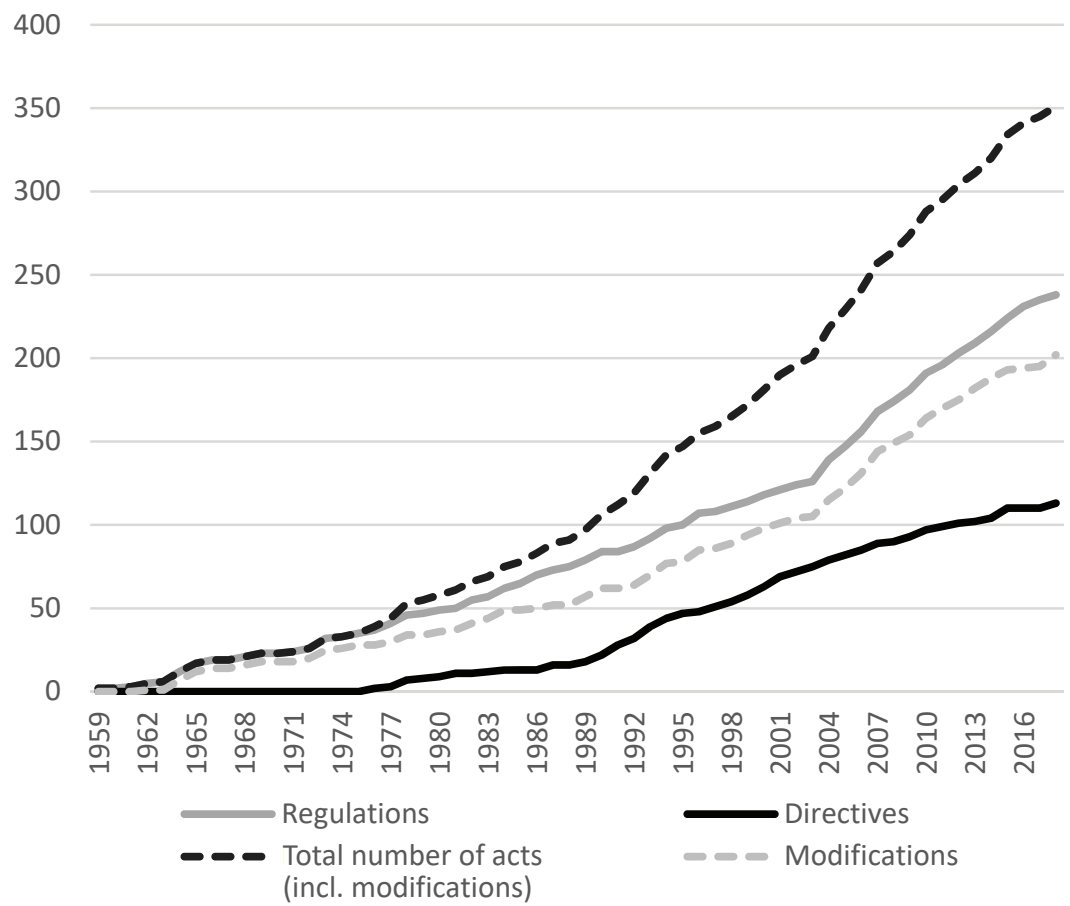

Figure 1: Aggregated number of EU Social Policy Acts (1958-2017, by year of adoption). The graph depicts aggregate numbers of regulatory social policy acts (dotted black line). Within this group, numbers for different instrument types are outlined separately (solid lines): regulations (grey) and directives (black). Modifications are also outlined separately (dotted grey line).

Source: Own compilation based on EurLex, including modifications but excluding geographical extension, acts addressing one member state only and acts exclusively based on the Euratom treaty

Comparing social policy with cross-sectoral dynamics in the EU two points are noteworthy. First, there is general agreement that legislative activity has slowed down with crisis responses and a changing role of the Commission as agenda setter. Yet, typically authors date this to occur as of 2009/ 2010 (Kassim et al. 2017). Social policy seems to differ. For directives decline started already 10 years earlier - at times of enlargement rather than in a crisis context. Regulations, in contrast, do not show signs of decline, rather their growth rate took up. Again, this differs from cross-sectoral developments, where Häge (2011: 466) notes a decline since 1992. Second, and somewhat qualifying the first point, modifications account for a large share of social policy developments through- 
out. This is in part natural as a revision process is frequently built into acts when first negotiated or external changes demand adaptation. And revision becomes necessary to integrate and clarify evolving case law (Martinsen 2015). Yet, while particularly in the 1980s and 1990s a majority of social policy acts provided new standards, today modifications are the rule.

Table 1: EU Regulatory social policy acts by area and instrument (1958-2017). Treaty articles are classified as market-supporting (MARKT) or own social right (OWNRIGHT), some articles do not fall in either category (not assigned - n.a.).

\begin{tabular}{|c|c|c|c|c|c|}
\hline Subject area & Total acts & Subfield & Regulations & Directives & Sum \\
\hline \multirow{4}{*}{$\begin{array}{l}\text { Free movement of } \\
\text { workers }\end{array}$} & 108 & Social security systems (MARKT) & 81 & 1 & 82 \\
\hline & & Worker mobility (MARKT) & 6 & 4 & 10 \\
\hline & & $\begin{array}{l}\text { Recognition of professional qualifica- } \\
\text { tion (MARKT) }\end{array}$ & 4 & 3 & 7 \\
\hline & & Right of residence (n.a.) & 3 & 6 & 9 \\
\hline \multirow{4}{*}{$\begin{array}{l}\text { Social } \\
\text { provisions }\end{array}$} & 86 & Health and safety at work (OWNRIGHT) & 2 & 43 & 45 \\
\hline & & Labour law (OWNRIGHT) & 0 & 26 & 26 \\
\hline & & Anti-discrimination (OWNRIGHT) & 1 & 12 & 13 \\
\hline & & Social insurance (OWNRIGHT) & 1 & 1 & 2 \\
\hline \multirow[t]{3}{*}{ Funding } & 45 & $\begin{array}{l}\text { European Social Fund (ESF) (OWN- } \\
\text { RIGHT) }\end{array}$ & 14 & 0 & 14 \\
\hline & & Direct distributions (OWNRIGHT) & 15 & 0 & 15 \\
\hline & & Others spending measures (OWNRIGHT) & 16 & 0 & 16 \\
\hline \multirow{2}{*}{$\begin{array}{l}\text { Management and } \\
\text { organization }\end{array}$} & 84 & Agencies and committees (n.a.) & 21 & 0 & 21 \\
\hline & & Data and statistics (n.a.) & 63 & 0 & 63 \\
\hline \multirow[t]{3}{*}{ Others } & 23 & European citizenship (OWNRIGHT) & 2 & 1 & 3 \\
\hline & & Health (OWNRIGHT) & 1 & 2 & 3 \\
\hline & & Transport (n.a.) & 8 & 9 & 17 \\
\hline Total acts & 346 & & 238 & 108 & 346 \\
\hline
\end{tabular}

Source: Own compilation based on EurLex, including modifications but excluding geographical extension, acts addressing one member state only and acts exclusively based on the Euratom treaty.

Absolute numbers of acts distribute unequally across subject areas. Table 1 shows that Free movement of workers is quantitatively most important (108), Social provisions (86) and Management and organization (84) follow suit. At a more disaggregated level Social security systems stands out as subfield being 
regulated most frequently (82). In contrast, Health and safety at work (45) as well as General labour law (26) show high numbers of acts too.

We now turn to the two logics of market-supporting versus social policy in its own right. Absolute numbers of acts classified as social policy in its own right outnumber market-supporting acts. The dominant logics and instrument types differ strongly across subject areas. Freedom of movement is supporting the market almost exclusively via regulations. Social provisions constitute social policy in its own right via directives and funding does so via regulations. The subject area management and organization is important for increasing numbers of regulations adopted in the fields Data and statistics (63), frequently regulating data collection in the context of the OMC, as well as Agencies and committees (21) that concern staff decisions. Here, regulation does not concern substantial policies and therefore does not provide leverage for the distinction between market-supporting social policy and social policy in its own right. The category Others in turn is a catch-all category that comprises acts that formally belong to other areas, but demonstrate a substantial link to social policy. ${ }^{5}$ Therefore the following analysis zooms into freedom of movement, social provisions and funding, as these areas are particularly relevant for a better understanding of dynamics and exploration of possible causes. ${ }^{6}$

\section{Comparing dynamics of market-supporting policy and social policy in its own right}

\subsection{Free Movement of Workers}

The movement of tourists, mobile workers, jobseekers, retirees and other persons in the EU is one of the four freedoms enshrined in the Treaties. Social regulation to support the free circulation of persons already figured in the Founding Treaty. Primarily this concerned coordination of Social security systems to address insecurity among workers. Figure 2 shows that the first regulation on the coordination of social security systems had been adopted in 1958 and has been revised frequently (today 883/2004/EC and implementing regulation 368/2014).

5 E.g. not all EU transport acts but only those addressing social provisions for transport workers etc.

6 Data on all policy fields can be found at http://www.polsoz.fuberlin.de/polwiss/forschung/international/de-fr/Team/Hartlapp/index.html. 
It connects national social security systems on age, unemployment, sickness, family benefits, invalidity as well as accidents at work. Rather than establishing common substantial standards, these acts seek to regulate the management of interfaces between national systems by assuring that entitlements are portable across countries. Member states are allowed to stick to their national systems as long as individuals are treated equally regardless of nationality. Following a similar logic, acts on Worker mobility address obstacles to mobility beyond social security systems, e.g. general rights to free movement or schooling of workers' children (77/486/EWG). Recognition of professional qualifications (last revision 2013/55/EC) in turn support the market by increasing transparency. Workers who want to exercise their profession in another country need to communicate knowledge and skills to a prospective client or employer. Clients and employers are dependent, in turn, on decoding the unknown qualification to match it with their needs.

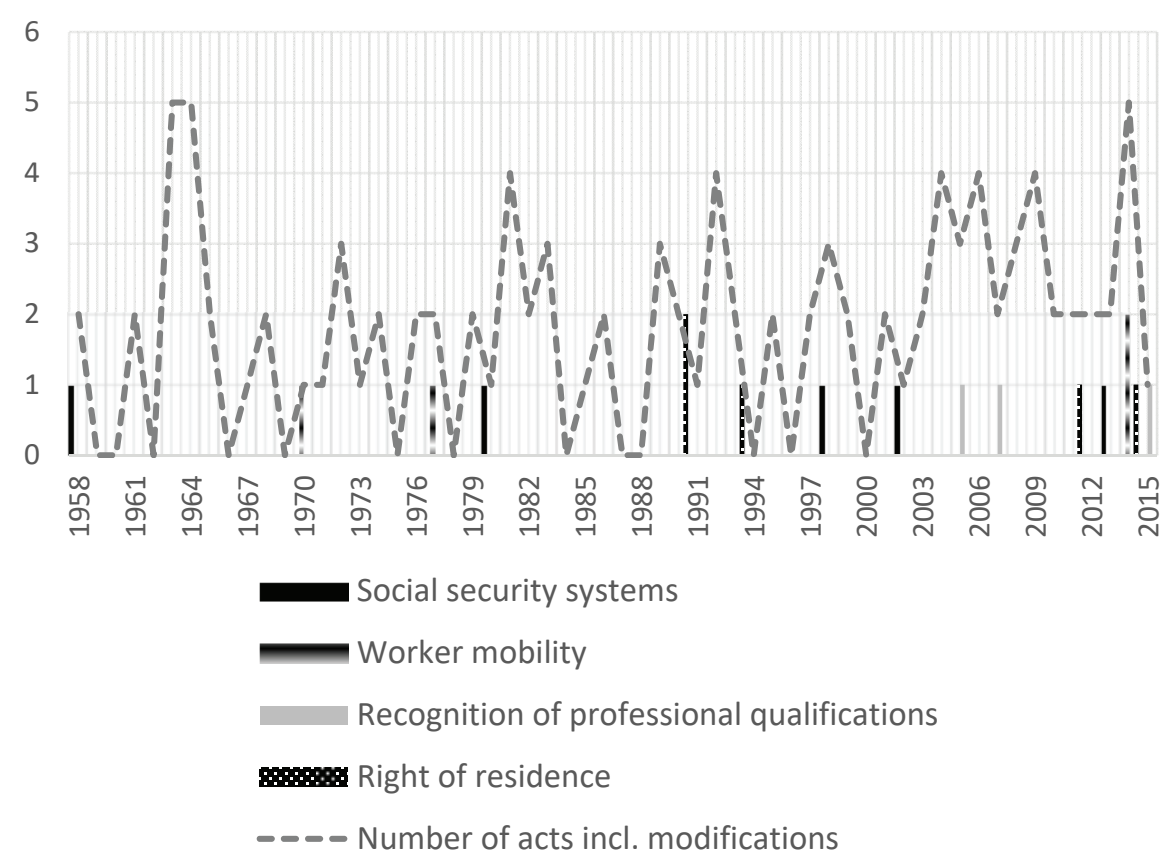

Figure 2: Development of regulatory acts on Free movement of workers (1958-2017)

Source: Own compilation based on EurLex, including modifications but excluding geographical extension, acts addressing one member state only and acts exclusively based on the Euratom treaty 
The Right of residence has been an issue since the 1990s. Initially it was related to worker mobility (Schmidt 2018: 75). Going beyond an understanding of individuals as workers or consumers, recent acts establish that there is a noneconomic right to mobility and residence in the EU (Eigmüller 2013: 371). An example is the "Right of workers to remain in the territory of a member state after having been employed in that state" (regulation No 635/2006). These developments were pushed by the Court of Justice of the EU in a number of famous cases that granted social rights independent of market participation (e.g. Dano C-333/13). Member States contest these developments and insisted on safeguards for access to national social security derived from the right of residence in case of 'unreasonable' burdens on national social security (Martinsen/Werner 2018). Public debates on welfare tourism show the potential for political conflict, where EU regulation pushes for social policy goals in their own right through the backdoor of market-making (Schmidt 2018: 128).

In sum, in the area of free movement of workers, we see that regulations dominate over directives and that there is a continuous dynamic toward a rather steady positive trend. Strikingly, modifications strongly dominate over new standards (17 acts only). Mobility of workers and transparency of skills is regulated to render the common market more efficient. Political changes, such as the increasing number and heterogeneity of member states, do not seem to show systematic effects. Put differently, we can characterize the regulatory dynamic as constant adaptation and adjustment.

\subsection{Social provisions}

In the subject area Social provisions, developments took off much later than for Free Movement of workers. Rather than displaying constant dynamics figure 3 demonstrates two striking 'high times' - with peaks in 1992 and 2000 - and a much more restrained dynamic before and after. Specific subfields drive these dynamics: Health and safety at work the first peak and Labour law the second peak. The subfield Anti-Discrimination played a smaller role throughout.

Health and safety at work acts protect workers against exposure to hazardous situations and substances. They harmonize rules for protective equipment and safety of machinery, such as national laws on safety signs at the workplace (77/576 EEC) or occupational exposure limits to vinyl chloride monomers (77/576 EEC). The adoption of a "Framework directive on Safety and Health at Work" (89/391/EEC) was followed by daughter directives on specific hazards 
(chemical agents 98/24/EC, biological agents 2000/54/EC, electromagnetic fields 2004/40/EC or asbestos 83/477/EEC). ${ }^{7}$ Labor law acts resemble issues in national legislation such as working time (93/104/EC) or industrial relations with directives on European Works Councils (94/45/EC), collective redundancies (98/59/EC) or information and consultation rules (2002/14/EC). In the 1990s, the social partners negotiated independently on a number of these acts. Later the Council adopted the agreements on parental leave (96/34/EC), parttime work (97/81/EC) and fixed-term contracts (1999/70/EC) as directives without changes in substance. In both subfields, the EU adopted few acts in the last 10 years. This is surprising given the historical importance of general Labour law and Health and safety at work for the EU social dimension.

More stable, in turn, are developments on Anti-discrimination. The Council adopted the first act that addressed equal pay for both sexes in 1975. Since, the EU has produced various directives in the sub-field. Today a number of discrimination grounds (gender, race, belief, disability, age and sexual orientation) with a wide scope are covered. Equal treatment is no longer limited to employment, but extends to social protection, including healthcare and social advantages, as well as goods and services available to the public and offered outside the area of private and family life (Hartlapp 2017). Over time, the sub-field has developed into a fully-fledged policy for more equal societies.

Finally, Social insurance acts address occupational pensions (2003/41/EC) and other measures targeted at older workers and their transition into old age security (e.g. decision No 940/2011/EU). Although competences firmly remain at the national level, the EU level regulation pursues social goals. Sometimes this is achieved through the backdoor of financial market instruments where transparency and protection of beneficiaries support genuine social goals (Haverland et al. 2018).

7 In addition to the goal to protect workers the development benefitted from industry supporting the free movement of machinery and protective equipment through harmonization (Scharpf 2002). 


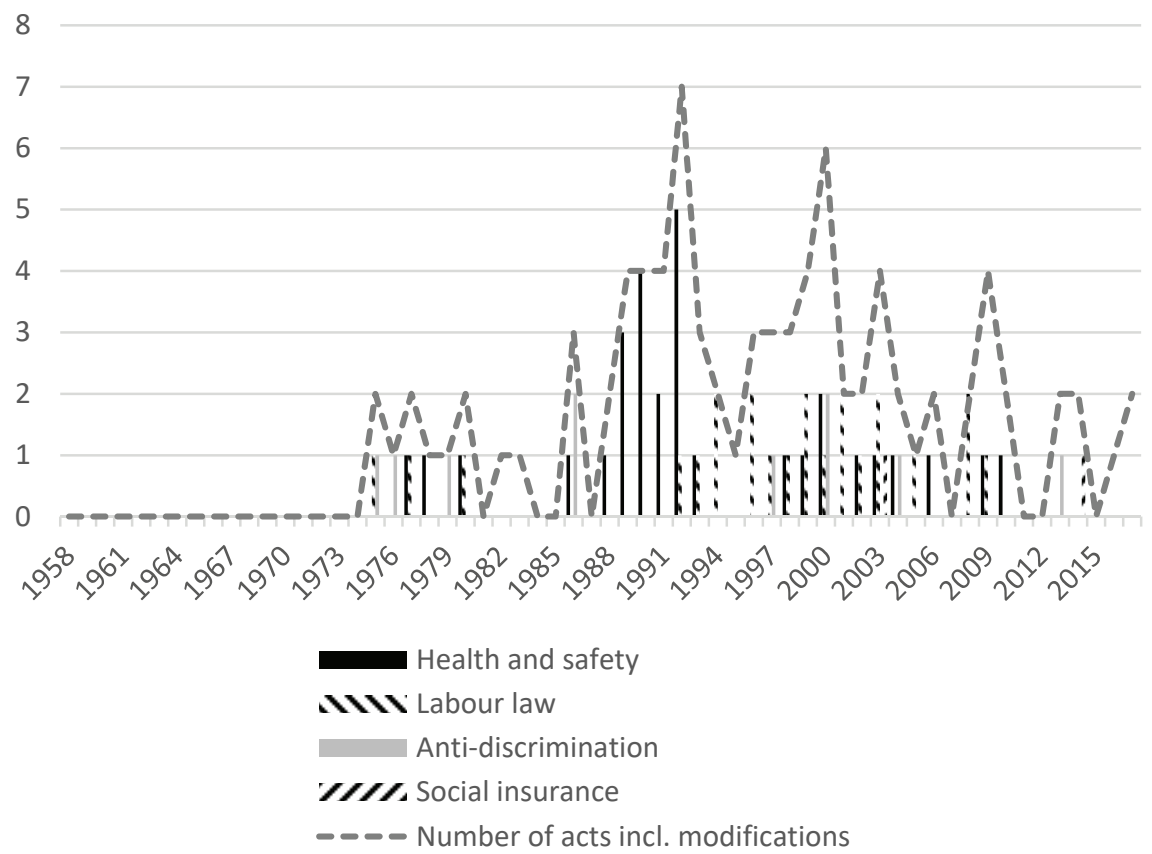

Figure 3: Development of regulatory acts on Social provisions (1958-2017)

Source: Own compilation based on EurLex, including modifications but excluding geographical extension, acts addressing one member state only and acts exclusively based on the Euratom treaty

Overall, instruments in the area Social provisions mostly seek social goals in their own right. Instruments are directives rather than regulations and there is a substantial variation in dynamic over time. Particularly dynamic periods in the 1990s and early 2000s contrast with a late take-off and recent inertia. It seems that here, social policy in its own right flourished at times when adoption was eased in terms of decision-making and fewer political contestations but ceased to do so after enlargement. This connection is discussed in more detail in section 6.

\subsection{Funding}

Funding policies require rules about how to distribute and spend money (LeviFaur 2014). Most regulatory acts in this area concern the European social fund 
(ESF) as figure 4 demonstrates. The EU developed its rules on how to spend money and whom to support in the first decades of integration. ESF financing, approximately 14 billion annually, targets employment support and investment in human capital. Regulations address administrative and financial aspects, intervention rates or the creation of new types of aid for specific groups of workers, e.g. young or self-employed (Regulation No 3824/85).

More recently, Other spending measures have diversified the instruments in this domain, such as the "Globalisation Adjustment Fund" (Regulation No 1927/2006) or the "Fund for European Aid to the Most Deprived" (Regulation No 223/2014). Creative usage of existing competences and household rules characterizes these funds (Hartlapp et al. 2014: chapter 5.2.5). Unlike the ESF acts, they address individual citizens and thus aim at increasing the visibility of the EU as a political entity with a social dimension for its citizens. Finally, the literature does not recognize the usage of EU agricultural goods (CAP) for Direct distribution as instruments of EU social policy. Yet, for our purposes, it is meaningful for its clear interventionist character and the idea of solidary support to those most in need. At the core of this policy is a regulation on the "supply of food from intervention stocks to designated organizations for distribution to the most deprived persons in the Community" (No 3744/87), which was adopted in 1987 and built on the milk-lakes and butter-mountains of the Common Agriculture Policy. Numerous modifications followed since and new acts are in the making (e.g. "milk for migrants" scheme).

In sum, the regulation of distributive social policies has been an important element of EU social policy from its inception. While the late 1990s and early 2000s were characterized by regulatory draught, we see a new dynamic since. Certainly limited in quantity, this positive dynamic contrasts with the decline in instruments classified as social policy in its own right in the other areas discussed so far. 


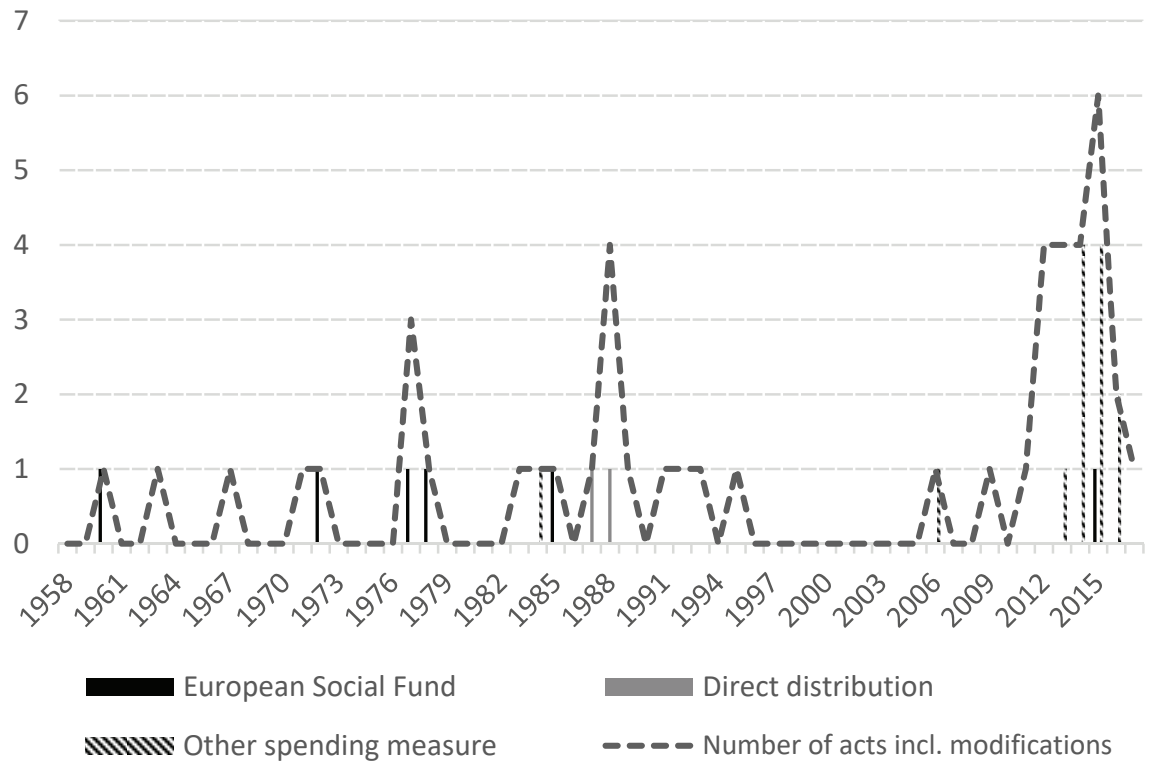

Figure 4: Development of regulatory acts on Funding (1958-2017)

Source: Own compilation based on EurLex, including modifications but excluding geographical extension, acts addressing one member state only and acts exclusively based on the Euratom treaty

\subsection{Discussion}

When we look across the three subject areas and subfields, three insights emerge. First, there are stark differences in terms of the type of instruments used. Typically, regulations are chosen to regulate Free movement of workers. Directives are much more typical for Social provisions. Second, timing and regulatory dynamics differ. Social standards related to freedom of movement have been adopted earlier and more steadily, while Social provisions or Funding show late take-off and an alteration between more and less dynamic periods. Third, the Free movement of workers is dominated by modifications rather than substantially new instruments that are relatively more relevant for Social provisions. What is important is that the lines along which these differences show coincide with our two logics. EU social policy supporting the market differs from EU social policy in its own right in type of instruments implemented, its timing and dynamic as well as its innovativeness, and - as I will argue in the next section its possible drivers. 


\section{Two types of social policy: exploring political drivers}

EU social acts supporting the market are more likely modifications than substantially new provisions. Their relatively continuous adoption seems to be largely unaffected by institutional and political developments. In particular, enlargements resulting in a higher number of Member States and a more heterogeneous Council with respect to national social policy models do not seem to render decision taking more difficult for this group of acts. Rather, developments seem to be perceived as functional necessity to establish or increase market efficiency independent of political majorities. On this basis, we may expect that EU social policy supporting the market is likely to continue developing.

This contrasts with patterns in the groups of acts classified as EU social policy in its own right. Independent of the instrument type (dominant directives for Social provisions and regulations for Funding) acts are more often addressing substantially new provisions than being modifications. Dynamics nicely respond to competence transfers. If we take into account a time lag of approximately two years for preparation and adoption of an act, the peaks emerge after the decision rules ease adoption of new acts at the EU level. This is most visible where high times following the Single European Act (1986) introduced new "rules on the working environment" and after the Maastricht Treaty (1992) transferred social policy competences for "information and consultation of workers" and "equality between men and women with regard to labor market opportunities and treatment at work". The Nice Treaty (2001) further extended qualified majority voting, too. Yet, despite these growing competences, regulatory activity has clearly been less dynamic. We can link this observation to a general understanding of institutional rules enabling or constraining actors. Yet, they do not fully determine action; interests are important influences, as well.

The data indicates that partisan politics might be a key determinant for social policy interests. The link has been theorized in comparative welfare state analysis where the strength of left (or Christian-democratic) parties holds strong explanatory power for the expansion of social policy (Schmidt 1996). Followingup on the distinction between a rather functional group of market-supporting social policies and a more politically contested group of EU social policy measures in their own right, we should expect that ideology plays out differently across these groups. Majorities of actors with a left orientation at the EU level should be particularly supportive of the adoption of social policy measures in 
their own right. Against the high numbers of liberal and conservative Commissioners in the Barroso Commissions (72,5\% under Barroso I and 70,2\% under Barroso II) it might thus be less surprising that fewer EU social policy directives have been proposed by the Commission recently (Graziano/Hartlapp 2018). To look at this more systematically, the partisan composition of Council and European Parliament would need consideration, too (Manow et al. 2007). Pursuing this line of reasoning has important implications for the question raised in the introduction. Where the current challenge to EU social policy depends on actors and their interests rather than on institutions and structures only, EU social policy can in principle be revived by changing political majorities.

\section{More market-supporting than social policy in its own right: what follows?}

Despite the fact that EU integration is largely driven by economic concerns, today the EU carries a substantial social dimension. The nature of this EU social policy is source of hopes as well as skepticism. This paper presented an original dataset of social policy output. It described patterns and dynamics across 346 regulatory acts adopted since the start of EU integration. The main finding is that over time the shape of regulatory social policy has substantially changed. It continues to be quite dynamic in areas connected to the market freedoms and dominated by regulations, strengthening its market-supporting dimension. Social policy in its own right that resembles more closely to social policy as we know it from the national level - e.g. General labour law- is in massive decline. Thus, regarding timing, part of regulatory social policy was already 'dead' before the crisis and the other part is growing rather than declining. And whether EU social policy meets demands or not might thus (at least in parts) depend on the empirical focus of analysis.

For this analysis the focus on regulatory social policy can be justified with the comparatively negligible volume of distributive policy (Schmid 2018: 177) and the attestation of a bias to follow economic rather than social goals in the OMCs (e.g. Copeland/Daly 2018). Nevertheless, future research would benefit from a more systematic comparison to empirically assess how typical the double-track patterns and dynamic are across EU social policy instruments, e.g. spending and coordinating instruments. This would also allow to explore across EU social policy instruments whether overlap between market-supporting social 
policy and social policy in its own right might be a characteristic of EU social policy.

Concerning the scope of the findings, existing research indicates that EU social policy seems to differ from cross-sectoral patterns, where declining dynamics concerning regulations came into effect later (Kassim et al. 2017; Häge 2011). This might be relevant for analysis of EU policy-making more widely, as we found that the differences in dynamics point at differences in the policymaking processes. The influence of institutional and political factors such as competence transfer, decision-rules and interests seems to differ across the subfields. Constant adaptations and adjustment to new market conditions are likely to drive regulation supporting the market. And where no far-reaching new standards are negotiated, diverging interests and institutions (e.g. as more clearly visible after enlargement) seem to have little effect on social policymaking. In contrast, where substantially new social standards in their own right are formulated, classical political factors such as heterogeneity of interests and ideology seem to be more important in explaining patterns. Thus, the present study confirms the need for research that looks at the role of interests and politics in addition to the explanations advanced in cross-sectoral studies of legislative activity, namely a better regulation agenda (Radaelli/Meuwese 2009) or crisis responses (Kassim et al. 2017).

\section{Bibliography}

Caporaso, James A.; Tarrow, Sidney (2009): "Polanyi in Brussels: Supranational Institutions and the Transnational Embedding of Markets", International Organization 63: 593-620.

Copeland, Paul; Daly, Mary (2012): "Varieties of poverty reduction: Inserting the poverty and social exclusion target into Europe 2020", Journal of European Social Policy 22: 273-287.

Copeland, Paul; Daly, Mary (2018): “The European Semester and EU Social Policy”, Journal of Common Market Studies 56: 1001-1018.

Copeland, Paul; Haar, Beryl ter (2013): “A toothless bite? The effectiveness of the European Employment Strategy as a governance tool”, Journal of European Social Policy 23: 21-36.

Crespy, Amandine; Vanheuverzwijn, Pierre (2017): “What 'Brussels' means by structural reforms: empty signifier or constructive ambiguity?", Comparative European Politics 20: 268.

De La Porte, Caroline; Heins, Elke (2015): “A new era of European Integration? Governance of labour market and social policy since the sovereign debt crisis", Comparative European Politics 13: 8-28.

De La Porte, Caroline; Natali, David (2018): “Agents of institutional change in EU policy: the social investment moment”, Journal of European Public Policy 25: 828-843.

Eigmüller, Monika (2013): “Europeanization from below: the influence of individual actors on the EU integration of social policies", Journal of European Social Policy 23: 363-375. 
Falkner, Gerda (1998): EU Social Policy in the 1990s: Towards a Corporatist Policy Community, London/New York: Routledge.

Falkner, Gerda; Treib, Oliver; Hartlapp, Miriam; Leiber, Simone (2004): Complying with Europe? The Impact of EU Minimum Harmonisation and Soft Law in the Member States. Book manuscript, under review.

Graziano, Paolo R.; Hartlapp, Miriam (2018): “The End of Social Europe? Understanding EU Social Policy Change", Journal of European Public Policy.

Guidi, Mattia; Guardiancich, Igor (2018): “Intergovernmental or supranational integration? A quantitative analysis of pension recommendations in the European Semester", European Union Politics 19: 684-706.

Haar, Beryl ter (2009): "The growing potential integration capacity of the acquis of the European Social Model”, European Integration Online Papers 13 (Art. 26).

Häge, Frank M. (2011): “The European Union Policy-Making dataset”, European Union Politics 12: 455-477.

Hartlapp, Miriam (2017): “How time empowers agency: Combining the EU Commission's political powers and its administration's advantage of acting from a long-term perspective”, Journal of European Integration 39: 303-317.

Hartlapp, Miriam; Metz, Julia; Rauh, Christian (2014): Which policy for Europe? Power and conflict inside the European Commission. Oxford: Oxford University Press.

Hartlapp, Miriam; Rauh, Christian (2013): “The Commission's Internal Conditions for Social ReRegulation. Market Efficiency and Wider Social Goals in Setting the Rules for Financial Services in Europe", European Journal of Government and Economics 2: 25-40.

Haverland, Markus; Ruiter, Minou de; van de Walle, Steven (2018): “Agenda-setting by the European Commission. Seeking public opinion?”, Journal of European Public Policy 25: 327-345.

Heidenreich, Martin; Zeitlin, Jonathan (2009): Changing European Employment and Welfare Regimes: The Influence of the Open Method of Coordination on National Reforms. London: Routledge.

Höpner, Martin; Schäfer, Armin (2012): “Embeddedness and Regional Integration. Waiting for Polanyi in a Hayekian Setting”, International Organization 66: 429-455.

Kahn-Nisser, Sara (2015): "The hard impact of soft co-ordination: emulation, learning, and the convergence of collective labour standards in the EU", Journal of European Public Policy 22: 1512-1530.

Kassim, Hussein; Connolly, Sara; Dehousse, Renaud; Rozenberg, Olivier; Bendjaballah, Selma (2017): "Managing the house: the Presidency, agenda control and policy activism in the European Commission", Journal of European Public Policy 24: 653-674.

Kröger, Sandra (2009): “What we have learnt: Advances, pitfalls and remaining questions of OMC research", European Integration online Papers, special issue 13(1).

Leibfried, Stephan; Pierson, Paul (eds.) (1995): European Social Policy. Between Fragmentation and Integration. Washington, D.C.: The Brookings Institution.

Levi-Faur, David (2014): “The welfare state: a regulatory perspective”, Public Administration 92: 599-614.

Lynggaard, Kennet (2016): “Exploring the emotional appeal of green and social Europe myths among pan-European Union organizations”, Journal of European Public Policy: 1-21.

Mailand, Mikkel; Arnholtz, Jens (2015): “Formulating European work and employment regulation during the pre-crisis years: Coalition building and institutional inertia”, Journal of European Social Policy 25: 194-209. 
Majone, Giandomenico (1993): "The European Community Between Social Policy and Social Regulation”, Journal of Common Market Studies 31: 153-170.

Manow, Philip; Schäfer, Armin; Zorn, Horn (2007): “Europe’s Party-Political Center of Gravity, 1957-2003”, Journal of European Public Policy 15: 20-39.

Maricut, Adina; Puetter, Uwe (2018): “Deciding on the European Semester: the European Council, the Council and the enduring asymmetry between economic and social policy issues", Journal of European Public Policy 25: 1-19.

Martinsen, Dorte Sindbjerg (2015): An Ever More Powerful Court? The Political Constraints of Legal Integration in the European Union. Oxford: Oxford University Press.

Martinsen, Dorte Sindbjerg; Werner, Benjamin (2018): "No welfare magnets - free movement and cross-border welfare in Germany and Denmark compared", Journal of European Public Policy: 1-19.

Prosser, Tony (2006): “Regulation and Social Solidarity”, Journal of Law and Society 33: 364387.

Radaelli, Claudio M.; Meuwese, Anne C. M. (2009): “Better regulation in Europe. Between Public Management and regulatory reform”, Public Administration 87: 639-654.

Ross, George (1994): “On Half-Full Glasses, Europe and the Left: Comments on Wolfgang Streeck's ,European Social Policy after Maastricht”, Economic and Industrial Democracy 15: 486-496.

Sbragia, Alberta; Stolfi, Francesco (2008): “Key Policies”, in: Elizabeth Bomberg; John Peterson; Alexander Stubb (eds.): The European Union: How Does it Work? Second edition. Oxford: Oxford University Press, 116-137.

Scharpf, Fritz W. (2002): “The European Social Model: Coping with the Challenges of Diversity", Journal of Common Market Studies 40: 645-670.

Schmid, Günther (2018): Europa in Arbeit. Plädoyer für eine neue Vollbeschäftigung durch inklusives Wachstum. Frankfurt/New York: Campus.

Schmidt, Manfred G. (1996): "When Parties Matter: A Review of the Possibilities and Limits of Partisan Influence on Public Policy”, European Journal of Political Research 30: 155-183.

Schmidt, Susanne K. (2018): The European Court of Justice \& the Policy Process. Oxford: Oxford University Press.

Streeck, Wolfgang (1995): “Neo-Voluntarism: A New European Social Policy Regime?”, European Law Journal 1: 31-59.

Windholz, Erich; Hodge, Graeme A. (2013): Conceptualising Social and Economic Regulation: Implications for Modern Regulators and Regulatory Activity. Jerusalem Papers in Regulation \& Governance. Working Paper No. 49 (Feburary 2013). 


\section{Short Biography}

Miriam Hartlapp is Professor for Comparative Politics: Germany and France at the Otto Suhr Institute at the Freie Universität Berlin (FUB). She researches European integration and its effects in nation states and, in doing so, has a particular interest for questions of power and conflict in the EU multi-level system as well as in economic and social policy.

Abstract: Auch wenn die Europäische Integration in erster Linie ein Prozess der Markt- und Wirtschaftsintegration ist, so hat die EU heute doch eine substantielle soziale Dimension. Dabei ist jedoch umstritten, ob diese soziale Dimension primär der Unterstützung der Marktintegration dient oder ob wir von einer eigenständigen EU-Sozialpolitik sprechen können. Letzteres wäre dann der Fall, wenn die soziale Dimension der EU Ziele wie soziale Gerechtigkeit, Solidarität und bessere Arbeitsbedingungen auch dann verfolgt, wenn diese nicht der Steigerung von Markteffizienz dienen oder wenn sie diesem Ziel sogar entgegenwirken. Der vorliegende Beitrag präsentiert einen neuen Datensatz mit allen 346 verbindlichen sozialpolitischen EU-Rechtsakten, die seit den Gründungsverträgen angenommen wurden. In einer deskriptiven Analyse werden Instrumente und Entwicklungsdynamiken in Teilbereichen, die eher einer marktunterstützenden Logik folgen, mit Teilbereichen kontrastiert, die genuin soziale Ziele verfolgen. Auf dieser Basis lässt sich aufzeigen, dass die Gestalt der EUSozialpolitik sich über die Zeit wesentlich gewandelt hat. Die marktunterstützende soziale Dimension wird kontinuierlich stärker, während die Entwicklungsdynamik bei Instrumenten mit genuin sozialen Zielen nachgelassen hat. Der Ausblick diskutiert politische Veränderungen als mögliche Erklärungsfaktoren dieser Entwicklungen. 